\title{
Effects of lipid sources, lysophospholipids and organic acids in maize-based broiler diets on nutrient balance, liver concentration of fat-soluble vitamins, jejunal microbiota and performance
}

\author{
G. V. Polycarpo, M. F. C. Burbarelli, A. C. P. CarÃo, C. E. B. Merseguel, \\ J. C. Dadalt, S. R. L. Maganha, R. L. M. Sousa, V. C. Cruz-Polycarpo \& R. \\ Albuquerque
}

To cite this article: G. V. Polycarpo, M. F. C. Burbarelli, A. C. P. CarÃo, C. E. B. Merseguel, J. C. Dadalt, S. R. L. Maganha, R. L. M. Sousa, V. C. Cruz-Polycarpo \& R. Albuquerque (2016) Effects of lipid sources, lysophospholipids and organic acids in maize-based broiler diets on nutrient balance, liver concentration of fat-soluble vitamins, jejunal microbiota and performance, British Poultry Science, 57:6, 788-798, DOI: 10.1080/00071668.2016.1219019

To link to this article: https://doi.org/10.1080/00071668.2016.1219019

Accepted author version posted online: 05 Aug 2016. Published online: 22 Sep 2016.

III Article views: 317

View Crossmark data $\nearrow$ 


\title{
Effects of lipid sources, lysophospholipids and organic acids in maize-based broiler diets on nutrient balance, liver concentration of fat-soluble vitamins, jejunal microbiota and performance
}

\author{
G. V. POlYCARPO (i), M. F. C. BURBARELli, A. C. P. CARÃO, C. E. B. MERSEGUEL, \\ J. C. DADALT, S. R. L. MAGANHA ${ }^{1}$, R. L. M. SOUSA ${ }^{1}$, V. C. CRUZ-POLYCARPO ${ }^{2}$, AND \\ R. ALBUQUERQUE
}

Department of Animal Nutrition and Production (VNP), University of São Paulo (FMVZ-USP), Pirassununga, Brazil, ${ }^{1}$ Department of Veterinary Medicine, University of São Paulo (FZEA-USP), Pirassununga, Brazil, and ${ }^{2}$ São Paulo State University (UNESP), Dracena, Brazil

\begin{abstract}
Three experiments with a $2 \times 2 \times 2$ factorial arrangement were conducted to evaluate maize-based diets for broilers containing different lipid sources [soybean oil (S) or beef tallow (T)] supplemented with or without lysophospholipids and organic acids on nutrient balance (Experiment I, evaluation period of 10-14 d), on liver concentration of fat-soluble vitamins, on jejunal microbiota (Experiment II, sampling at d 14) and on performance (Experiment III, accumulated periods of 1-14, 1-21 and 1-42 d).

2. A total of 1344 male chicks were used. In each experiment, the birds were allotted in a completely randomised design with 8 replications. The lysophospholipids were mainly composed of lysolecithins and the organic acids blend was constituted by lactic $(40 \%)$, acetic $(7 \%)$ and butyric acids $(1 \%)$.

3. An interaction between lipid sources and lysophospholipids was observed on faecal apparent digestibility of lipid (ADL), which improved with lysophospholipids addition in T diets. Broilers fed on S had higher ADL and faecal apparent digestibility of nitrogen-corrected gross energy ( $\left.\mathrm{ADGE}_{\mathrm{N}}\right)$.

4. It was not possible to demonstrate a significant treatment effect on the liver concentration of vitamins $\mathrm{A}$ and $\mathrm{E}$, even with the differences in fatty acid profile between $\mathrm{S}$ and $\mathrm{T}$.

5. Enterobacteria values were below the detection threshold. Lysophospholipid supplementation reduced gram-positive cocci in T-fed birds. S diets promoted lower total anaerobe counts compared with $\mathrm{T}$ diets, independent of additives.

6. S diets increased BW gain and feed:gain ratio in all evaluation periods. Lysophospholipids and organic acids improved feed:gain ratio at 1-21 d in T diets. Furthermore, main effects were observed for lysophospholipids and organic acids at 1-42 d, which increased BW gain and improved feed:gain ratio, respectively. 7. No positive interactions between additives were found.
\end{abstract}

\section{INTRODUCTION}

The inclusion of lipids in broiler diets is essential for the metabolisable energy requirement to be properly met. Within this reality, researches have been conducted to study the increased digestibility of oils and fats by emulsifying substances, such as bile salts (Polin et al., 1980; Kussaibati et al., 1982) and phospholipids (Azman and Ciftci, 2004; Huang et al.,
2007 , 2008). Recently, some studies were performed to evaluate lysophospholipids as exogenous emulsifiers in poultry diets (Raju et al., 2011; Zhang et al., 2011), which are originated by the action of the phospholipase $\mathrm{A}_{2}$ pancreatic enzyme on phospholipids. The conversion of phospholipids to lysophospholipids modifies the molecule chemical characteristics that greatly increase the critical micelle concentration (Stafford and Dennis, 1988).

Correspondence to: G. do Valle Polycarpo, Department of Animal Nutrition and Production (VNP), University of São Paulo (FMVZ-USP), Av. Duque de Caxias Norte, 225, Pirassununga, SP 13635-900, Brazil. E-mail: gupolycarpo@usp.br

Accepted for publication 28 April 2016. 
This process is fundamental and occurs naturally in bird's fat digestion, which supports this technology application in poultry nutrition through exogenous supplementation. Recently, Jansen et al. (2015) confirmed in broiler chickens an increased metabolisable energy due to the lysophospholipids utilisation in the feed.

Another action of lysophospholipids is related to the antibacterial effect (Coonrod and Yoneda, 1983). They may modify the biological structure of bacteria causing changes in membrane permeability (Arouri and Mouritsen, 2013), raising the speculation of a combined effect with organic acids on poultry gut health (Tamblyn and Conner, 1997; Alakomi et al., 2000; Zhao et al., 2009). The changes in membrane permeability by lysophospholipids may facilitate the ion dissociation of the organic acids inside the bacteria. In turn, the control of the intestinal microbiota through these additives could preserve the integrity of endogenous bile salts (Feighner and Dashkevicz, 1987; Knarreborg et al., 2002a), especially in diets with large amounts of saturated fatty acids (Knarreborg et al., 2002b), improving fat digestion. Some investigations around the antimicrobial effects of the organic acids exist (Ricke, 2003; Van Immerseel et al., 2006), but so far there is no evidence in the literature about the action of lysophospholipids on broiler microbiota.

Therefore, the aim of this study was to evaluate diets for broiler chickens containing soybean oil (S) or beef tallow (T) with or without lysophospholipid and organic acid supplementation on nutrient balance, liver concentration of fat-soluble vitamins, jejunal microbiota and performance.

\section{MATERIALS AND METHODS}

The trials were conducted in accordance with the ethical principles of animal experimentation established by the Ethics Committee of Animal Use of University of São Paulo - USP (Brazil), protocol number 2737/2012.

\section{Experimental design and diets}

A $2 \times 2 \times 2$ factorial arrangement was used in a completely randomised design to evaluate the effects of two lipid sources ( $\mathrm{S}$ or $\mathrm{T}$ ) with or without lysophospholipids and organic acids. Diets were maize and soybean meal based and had similar energy and amino acid levels according to the values recommended by Rostagno et al. (2011) (Table 1). To balance the higher energy value of $\mathrm{S}$, the exact amount of starch included replacing kaolin (inert material) in $\mathrm{T}$ diets was previously calculated in order to adjust the energy value of diets with different lipid sources. The additives were included "on top" in replacement of the inert material according to each treatment. The lysophospholipids were composed mainly by lysolecithins, which is an emulsifier produced from enzymatic enrichment of soybean lecithin by the enzyme phospholipase $\mathrm{A}_{2}$ activity, mainly producing lysophosphatidylcholine. The organic acids blend was: lactic $(40 \%)$, acetic $(7 \%)$ and butyric acids $(1 \%)$. Antibiotics and coccidiostats were omitted from the diets to avoid any interference with the proposed additives. Water and mash feed were provided ad libitum.

The calculated fatty acids composition of the diets was carried out based on the analysis of all ingredients that had lipid fractions (Table 2). The fatty acid profile was determined using the fat extraction method described by Bligh and Dyer (1959), Christie (1982) and Smedes and Thomasen (1996). The separated fat was methylated yielding methyl esters formed according to Kramer et al. (1997). Two internal standards, C18:0 and C19:0 (Sigma Aldrich ${ }^{\circledR}$ ), were used to correct for losses during the methylation process. The fatty acids were quantified by gas chromatography (GC Shimadzu, 2010, with automatic injection) using SP-2560 capillary column (100 m x $0.25 \mathrm{~mm}$ diameter with $0.02 \mathrm{~mm}$ thickness, Supelco, Bellefonte, PA). The initial temperature was $70^{\circ} \mathrm{C}$ for $4 \mathrm{~min}\left(13^{\circ} \mathrm{C} \mathrm{min}^{-1}\right)$ until $175^{\circ}$ $\mathrm{C}$ and holding for $27 \mathrm{~min}$. Then, another increase of $4^{\circ} \mathrm{C}$ min $^{-1}$ was started up to $215^{\circ} \mathrm{C}$ and holding for $31 \mathrm{~min}$. Hydrogen $\left(\mathrm{H}_{2}\right)$ was used as carrier gas with a flow of $40 \mathrm{~cm} \mathrm{~s}^{-1}$. The following 4 patterns were used during the identification process: Standard C4-24 of fatty acids (Supelco ${ }^{\circledR}$ TM 37), vaccenic acid C18:1 trans-11 (V038-1G, Sigma ${ }^{\circledR}$ ) and CLA C18:2: trans-10, cis-12 (UC-61 M $100 \mathrm{mg}$ ), C18:2 cis-9, trans-11 (UC60 M 10083 mg), (NU-CHEK-PREP EUA ${ }^{\circledR}$ ).

\section{Birds}

A total of 1344 one-d-old male $\mathrm{Cobb}^{\circledR}$ chicks were used. The initial average weight in the performance experiment (Experiment III) was $46.16 \mathrm{~g} \pm 0.608 \mathrm{~g}$ $(P>0.05)$.

\section{Experiment I - nutrient balance}

For assessment of nutritional balance by the total excreta collection method, 448 chicks were allocated to the 8 treatments with 8 replications and 7 birds per experimental unit. The birds were placed into metabolic cages fitted with front feeder, nipple drinker and stainless steel trays for excreta collection. A 24-h lighting programme was employed. Metabolic assays occurred from 6 to $14 \mathrm{~d}$, with $4 \mathrm{~d}$ of adaptation to the experimental diets and 4 more days for excreta collection, performed twice daily. 
Table 1. Composition of the experimental diets

\begin{tabular}{|c|c|c|c|c|c|c|c|c|}
\hline \multirow[b]{3}{*}{ Ingredients ( $\mathrm{g} / \mathrm{kg}$ of natural matter) } & \multicolumn{8}{|c|}{$\operatorname{Diets}^{1}$} \\
\hline & \multicolumn{2}{|c|}{$1-7 \mathrm{~d}$} & \multicolumn{2}{|c|}{$8-21 \mathrm{~d}$} & \multicolumn{2}{|c|}{$22-33 \mathrm{~d}$} & \multicolumn{2}{|c|}{$34-42 \mathrm{~d}$} \\
\hline & $\mathrm{S}$ & $\mathrm{T}$ & $\mathrm{S}$ & $\mathrm{T}$ & $\mathrm{S}$ & $\mathrm{T}$ & $\mathrm{S}$ & $\mathrm{T}$ \\
\hline Maize meal $7.88 \%$ & 531.45 & & 584.72 & & 611.13 & & 648.67 & \\
\hline Soybean meal $45 \%$ & 369.01 & & 326.45 & & 298.01 & & 269.48 & \\
\hline Maize gluten $60 \%$ & 5.92 & & 0.72 & & 3.68 & & 0.94 & \\
\hline Soybean oil & 27.00 & - & 27.00 & - & 31.50 & - & 31.50 & - \\
\hline Beef tallow & - & 27.00 & - & 27.00 & - & 31.50 & - & 31.50 \\
\hline Starch & - & 10.63 & - & 10.63 & - & 12.40 & - & 12.40 \\
\hline Sodium chloride & 3.50 & & 3.50 & & 3.50 & & 3.50 & \\
\hline Sodium bicarbonate & 2.33 & & 1.96 & & 1.59 & & 1.39 & \\
\hline Dicalcium-phosphate & 19.28 & & 15.26 & & 13.25 & & 10.36 & \\
\hline Limestone & 9.09 & & 10.35 & & 8.90 & & 8.28 & \\
\hline L-Lysine & 3.20 & & 2.44 & & 2.05 & & 1.95 & \\
\hline DL-Methionine & 3.57 & & 2.84 & & 2.43 & & 2.14 & \\
\hline L-Threonine & 1.16 & & 0.72 & & 0.40 & & 0.31 & \\
\hline L-Valine & 0.86 & & 0.41 & & 0.16 & & 0.08 & \\
\hline Lysophospholipids $^{2}$ & 1.00 & & 1.00 & & 1.00 & & 1.00 & \\
\hline${\text { Organic } \text { acids }^{2}}^{2}$ & 8.00 & & 8.00 & & 6.00 & & 4.00 & \\
\hline Kaolin & 10.63 & - & 10.63 & - & 12.40 & - & 12.40 & - \\
\hline Vitamin and mineral premix ${ }^{3}$ & 4.00 & & 4.00 & & 4.00 & & 4.00 & \\
\hline \multicolumn{9}{|l|}{ Calculated composition, $\mathrm{g} / \mathrm{kg}$} \\
\hline $\mathrm{AME}_{\mathrm{N}}, \mathrm{MJ} / \mathrm{kg}$ & 12.25 & & 12.48 & & 12.77 & & 12.98 & \\
\hline Crude protein & 220.0 & & 200.0 & & 190.0 & & 178.0 & \\
\hline Ether extract & 52.6 & & 53.7 & & 58.7 & & 59.6 & \\
\hline Crude fibre & 28.82 & & 27.43 & & 26.41 & & 25.51 & \\
\hline Calcium & 9.20 & & 8.60 & & 7.50 & & 6.50 & \\
\hline Available phosphorus & 3.95 & & 3.37 & & 3.07 & & 2.66 & \\
\hline Lysine $^{4}$ & 13.04 & & 11.41 & & 10.45 & & 9.69 & \\
\hline Methionine + cystine $^{4}$ & 9.39 & & 8.22 & & 7.63 & & 7.07 & \\
\hline Threonine $^{4}$ & 8.48 & & 7.42 & & 6.79 & & 6.30 & \\
\hline Valine $^{4}$ & 10.04 & & 8.79 & & 8.15 & & 7.56 & \\
\hline Sodium & 2.20 & & 2.10 & & 2.00 & & 1.95 & \\
\hline
\end{tabular}

${ }^{1} \mathrm{~S}$, soybean oil; T, beef tallow.

${ }^{2}$ Additives were replaced by kaolin to obtain the treatments without additives. Lysophospholipids $=$ Lysoforte ${ }^{\mathrm{TM}}$, supplied by Kemin ${ }^{\circledR}$. Organic acids = Premium Lac $®$, supplied by Nutriacid/Btech

${ }^{3}$ Vitamin and mineral premix provided: retinyl acetate, $2.40 \mathrm{mg}$; cholecalciferol, $0.60 \mathrm{mg}$; $\alpha$-tocopherol acetate, $12.00 \mathrm{mg}$; menadione, $2.00 \mathrm{mg}$; thiamine, $2.40 \mathrm{mg}$; riboflavin, $6.00 \mathrm{mg}$; pyridoxine, $4.00 \mathrm{mg}$; cyanocobalamin, $0.014 \mathrm{mg}$; niacin, $40.00 \mathrm{mg}$; pantothenic acid, $15.00 \mathrm{mg}$; folic acid, $1.00 \mathrm{mg}$; choline, $346.40 \mathrm{mg}$; Fe, $50.00 \mathrm{mg}$; Mn, $70.00 \mathrm{mg} ; \mathrm{Zn}, 50.00 \mathrm{mg}$; Cu, $10.00 \mathrm{mg}$; I, $1.20 \mathrm{mg}$; Se, $0.20 \mathrm{mg}$ per kg of the pre-starter diet (1-7 d); retinyl acetate, $2.10 \mathrm{mg}$; cholecalciferol, $0.55 \mathrm{mg}$; $\alpha$-tocopherol acetate, $11.00 \mathrm{mg}$; menadione, $1.60 \mathrm{mg}$; thiamine, $2.00 \mathrm{mg}$; riboflavin, $5.00 \mathrm{mg}$; pyridoxine, $3.00 \mathrm{mg}$; cyanocobalamin, $0.012 \mathrm{mg}$; niacin, $35.00 \mathrm{mg}$; pantothenic acid, $13.00 \mathrm{mg}$; folic acid, $0.80 \mathrm{mg}$; choline, $328.00 \mathrm{mg}$; Fe, $50.00 \mathrm{mg}$; Mn, $70.00 \mathrm{mg}$; Zn, $50.00 \mathrm{mg} ; \mathrm{Cu}, 10.00 \mathrm{mg}$; I, $1.20 \mathrm{mg}$; Se, $0.20 \mathrm{mg}$ per kg of the starter diet (8-21 d); retinyl acetate, $1.80 \mathrm{mg}$; cholecalciferol, $0.50 \mathrm{mg}$; $\alpha$-tocopherol acetate, $10.00 \mathrm{mg}$; menadione, $1.60 \mathrm{mg}$; thiamine, $1.40 \mathrm{mg}$; riboflavin, $4.00 \mathrm{mg}$; pyridoxine, $2.00 \mathrm{mg}$; cyanocobalamin, $0.010 \mathrm{mg}$; niacin, $30.00 \mathrm{mg}$; pantothenic acid, $11.00 \mathrm{mg}$; folic acid, $0.60 \mathrm{mg}$; choline, $241.60 \mathrm{mg}$; Fe, $50.00 \mathrm{mg}$; Mn, $70.00 \mathrm{mg}$; $\mathrm{Zn}, 50.00 \mathrm{mg}$; Cu, $10.00 \mathrm{mg}$; I, $1.20 \mathrm{mg}$; Se, $0.20 \mathrm{mg}$ per $\mathrm{kg}$ of the grower diet (22-33 d); retinyl acetate, $1.50 \mathrm{mg}$; cholecalciferol, $0.25 \mathrm{mg} ; \alpha$-tocopherol acetate, $8.00 \mathrm{mg}$; menadione, $1.60 \mathrm{mg}$; riboflavin, $2.00 \mathrm{mg}$; cyanocobalamin, $0.005 \mathrm{mg}$; niacin, $20.00 \mathrm{mg}$; pantothenic acid, $9.00 \mathrm{mg}$; choline, $127.60 \mathrm{mg}$; Fe, $50.00 \mathrm{mg}$; Mn, $70.00 \mathrm{mg}$; Zn, $50.00 \mathrm{mg}$; Cu $8.00 \mathrm{mg}$; I, $1.20 \mathrm{mg}$; Se, $0.20 \mathrm{mg}$ per $\mathrm{kg}$ of the final diet (34-42 d).

${ }^{4}$ Digestible values.

Excreta were packed in plastic bags, identified by replication and stored in a freezer at $-16^{\circ} \mathrm{C}$. At the end of the experimental period, feed intake and total excreta produced were determined. Further, excreta samples were thawed and homogenised. A sample from each replicate was removed and dried at $55^{\circ} \mathrm{C}$ for $72 \mathrm{~h}$. Subsequently, samples were weighed, finely ground and packed for laboratory analysis according to AOAC (1990).

Dry matter contents were determined at $105^{\circ} \mathrm{C}$ for $12 \mathrm{~h}$ and nitrogen values were obtained using the micro-Kjeldahl technique. The ether extract was analysed gravimetrically after extraction using petroleum ether in a Soxhlet extractor. Gross energy was measured by adiabatic calorimetry bomb $\left(\mathrm{IKA}^{\circledR}\right.$ model C5003), using benzoic acid as a standard for calibration. Diets and excreta samples were analysed to determine the values of the faecal apparent digestibility of dry matter (ADDM), nitrogen (ADN), lipids (ADL) and gross energy corrected by nitrogen balance $\left(\mathrm{ADGE}_{\mathrm{N}}\right) \cdot \mathrm{ADGE}_{\mathrm{n}}$ was calculated using values for apparent metabolisable energy corrected to zero nitrogen balance $\left(\mathrm{AME}_{\mathrm{N}}\right)$ obtained by use of the equations proposed by Matterson et al. (1965). 
Table 2. Fatty acid profile of the experimental diets

\begin{tabular}{|c|c|c|c|c|c|c|c|c|}
\hline \multirow[b]{3}{*}{$\mathrm{g} / 100 \mathrm{~g}$ of fatty acids } & \multicolumn{8}{|c|}{ Diets $^{1}$} \\
\hline & \multicolumn{2}{|c|}{$1-7 \mathrm{~d}$} & \multicolumn{2}{|c|}{$8-21 \mathrm{~d}$} & \multicolumn{2}{|c|}{$22-33 \mathrm{~d}$} & \multicolumn{2}{|c|}{$34-42 \mathrm{~d}$} \\
\hline & $\mathrm{S}$ & $\mathrm{T}$ & $S$ & $\mathrm{~T}$ & $\mathrm{~S}$ & $\mathrm{~T}$ & S & $\mathrm{T}$ \\
\hline C10:0 & 0.02 & 0.05 & 0.02 & 0.05 & 0.02 & 0.05 & 0.02 & 0.05 \\
\hline C12:0 & 0.13 & 0.21 & 0.14 & 0.22 & 0.14 & 0.22 & 0.14 & 0.22 \\
\hline C14:0 & 0.14 & 1.61 & 0.14 & 1.58 & 0.13 & 1.67 & 0.13 & 1.65 \\
\hline C14:1 cis-9 & - & 0.27 & - & 0.27 & - & 0.28 & - & 0.28 \\
\hline C15:0 & - & 0.31 & - & 0.30 & - & 0.32 & - & 0.32 \\
\hline C16:0 & 12.14 & 20.11 & 12.08 & 19.89 & 11.97 & 20.30 & 11.94 & 20.15 \\
\hline C16:1 cis-9 & 0.20 & 1.47 & 0.20 & 1.44 & 0.19 & 1.52 & 0.19 & 1.50 \\
\hline C17:0 & 0.05 & 0.66 & 0.04 & 0.64 & 0.05 & 0.68 & 0.05 & 0.67 \\
\hline C18:0 & 3.74 & 12.90 & 3.75 & 12.72 & 3.72 & 13.28 & 3.73 & 13.16 \\
\hline C18:1 trans -9 & - & 0.10 & - & 0.10 & - & 0.11 & - & 0.10 \\
\hline C18:1 trans-11 & - & 1.35 & - & 1.32 & - & 1.41 & - & 1.39 \\
\hline C18:1 cis-9 & 25.26 & 32.72 & 25.59 & 32.89 & 25.49 & 33.28 & 25.70 & 33.38 \\
\hline C18:2 cis-9, 12 & 53.30 & 25.89 & 53.15 & 26.30 & 53.36 & 24.71 & 53.26 & 25.01 \\
\hline C18:2 cis-9, trans -11 & - & 0.25 & - & 0.25 & - & 0.27 & - & 0.26 \\
\hline C18:3 cis-9, 12, 15 & 4.17 & 1.39 & 4.02 & 1.30 & 4.08 & 1.18 & 3.99 & 1.13 \\
\hline C20:0 & 0.42 & 0.35 & 0.43 & 0.36 & 0.43 & 0.35 & 0.43 & 0.36 \\
\hline C20:1 cis-11 & 0.07 & 0.16 & 0.07 & 0.17 & 0.07 & 0.17 & 0.07 & 0.17 \\
\hline C20:2 cis-11, 14 & 0.02 & 0.03 & 0.02 & 0.03 & 0.02 & 0.04 & 0.02 & 0.04 \\
\hline C20:3 cis-8, 11, 14 & - & 0.01 & - & 0.01 & - & 0.01 & - & 0.01 \\
\hline $\mathrm{C} 20: 4$ cis-5, 8, 11, 14 & - & 0.03 & - & 0.03 & - & 0.03 & - & 0.03 \\
\hline C21:0 & 0.02 & 0.01 & 0.02 & 0.01 & 0.02 & 0.01 & 0.02 & 0.01 \\
\hline C22:0 & 0.30 & 0.11 & 0.30 & 0.11 & 0.30 & 0.10 & 0.30 & 0.10 \\
\hline C23:0 & 0.02 & $<0.01$ & 0.02 & $<0.01$ & 0.02 & $<0.01$ & 0.02 & $<0.01$ \\
\hline \multicolumn{9}{|l|}{$\Sigma$} \\
\hline Saturated & 16.98 & 36.31 & 16.95 & 35.88 & 16.79 & 36.99 & 16.78 & 36.70 \\
\hline Unsaturated & 83.02 & 63.69 & 83.05 & 64.12 & 83.21 & 63.01 & 83.22 & 63.30 \\
\hline Monounsaturated & 25.53 & 36.08 & 25.86 & 36.19 & 25.75 & 36.77 & 25.96 & 36.83 \\
\hline Polyunsaturated & 57.49 & 27.61 & 57.19 & 27.93 & 57.46 & 26.24 & 57.27 & 26.48 \\
\hline Unsaturated/Saturated & 4.89 & 1.75 & 4.90 & 1.79 & 4.95 & 1.70 & 4.96 & 1.73 \\
\hline$\omega-9$ & 25.33 & 32.98 & 25.66 & 33.16 & 25.56 & 33.56 & 25.77 & 33.66 \\
\hline$\omega-7$ & 0.20 & 3.09 & 0.20 & 3.01 & 0.19 & 3.19 & 0.19 & 3.15 \\
\hline$\omega-6$ & 53.32 & 25.96 & 53.17 & 26.37 & 53.38 & 24.79 & 53.28 & 25.09 \\
\hline$\omega-3$ & 4.17 & 1.39 & 4.02 & 1.30 & 4.08 & 1.18 & 3.99 & 1.13 \\
\hline$\omega-6 / 3$ & 12.79 & 18.63 & 13.22 & 20.22 & 13.08 & 20.99 & 13.35 & 22.21 \\
\hline
\end{tabular}

${ }^{1} \mathrm{~S}$, soybean oil; $\mathrm{T}$, beef tallow.

\section{Experiment II - biological sample collection}

A total of 128 birds raised in floor pens were killed when they were $14 \mathrm{~d}$ old. The 8 experimental diets were replicated 8 times, where one bird represented the experimental unit. The diets were supplied from the first day. A total of 64 birds were used to evaluate the concentration of liver fat-soluble vitamins and the other 64 birds for the jejunal microbiological analysis. All birds were raised individually, totalling 128 boxes $(1.00 \mathrm{~m} \times 1.20 \mathrm{~m})$ with tubular feeder and nipple drinker. A 24-h lighting programme was used and the litter was a rice husk recycled.

\section{Fat-soluble vitamins}

The livers taken from the birds were immediately frozen in liquid nitrogen to determine the concentration of vitamins $\mathrm{A}$ and $\mathrm{E}$, identified as retinol and $\alpha$-tocopherol, respectively. The liver samples were macerated; saturated ethanol was added with ascorbic acid together with $3 \mathrm{ml}$ of saturated $\mathrm{NaCl}$ solution. Then, the mixture was homogenised, adding $5 \mathrm{ml}$ of hexane solvent containing 2\% 2-propanol and $0.01 \%$ BHT (Butylated hydroxytoluene). The mixture was homogenised using vortex for $1 \mathrm{~min}$ and centrifuged for $5 \mathrm{~min}$ at $2400 \mathrm{~g}$. The supernatant was removed (organic phase) into a second flask and the procedure repeated with the sample, adding another $5 \mathrm{ml}$ of hexane solvent. The organic phase was dried with nitrogen, reconstituted with mobile methanol/water phase $(98 \% / 2 \%$, $\mathrm{v} / \mathrm{v})$ and injected into the liquid chromatograph.

The extracts of vitamins $\mathrm{A}$ and $\mathrm{E}$ were analysed by liquid chromatography with ultraviolet detection (LC-UV) and by liquid chromatography with detection of in tandem mass spectrometry (LC-MS/MS). The chromatographic conditions for the LC-UV: Chromatograph Agilent Series 1200; column Nucleosil Shell RP 18 $(100 \mathrm{~mm} \quad \mathrm{x} \quad 4.6 \mathrm{~mm} \quad \mathrm{x} \quad 2.7 \quad \mu \mathrm{m})$, mobile 
methanol/water phase $(98 \% / 2 \% \mathrm{v} / \mathrm{v})$ with a wavelength of $325 \mathrm{~nm}$ for vitamin A and $290 \mathrm{~nm}$ for vitamin $\mathrm{E}$, injecting a volume of $20 \mu \mathrm{l}$, a flow $\mathrm{ml} /$ min. The chromatographic conditions for the LCMS/MS Chromatograph Agilent 1200 were: column Nucleosil Shell RP 18 $(100 \mathrm{~mm} \times 4.6 \mathrm{~mm} \times 2.7 \mu \mathrm{m})$, mobile phase water $+0.1 \%$ formic acid and methanol $+0.1 \%$ formic acid $(2 \% / 98 \%, \mathrm{v} / \mathrm{v})$, injected volume of $10 \mu \mathrm{l}$ and a flow $1 \mathrm{ml} \mathrm{m^{-1 }}$. Mass Spectrometer 3200 QTRAP (Linear Ion Trap Quadrupole LC/ MS/MS Mass Spectrometer), electrospray ionisation, positive mode. For vitamin A, the precursor ion $(\mathrm{m} / \mathrm{z})$ and fragment ion $(\mathrm{m} / \mathrm{z})$ were 269 and 93, 91 and 77; and for vitamin E, were 431 and 165,137 and 69 , respectively.

\section{Jejunal microbiota}

Birds were killed and the digestive tract was quickly dissected. Samples were collected from the jejunum (bile duct entrance to Meckel's diverticulum) with the aid of small wooden spatulas previously autoclaved. The samples were immediately frozen at $-20^{\circ} \mathrm{C}$ until subsequent analysis. A $0.5 \mathrm{~g}$ of sample was diluted in $4.5 \mathrm{ml}$ of peptone water previously autoclaved $\left(10^{-1}\right.$ dilution). The content was homogenised and $1 \mathrm{ml}$ of the solution was transferred to another tube with $9 \mathrm{ml}$ of peptone water. A serial dilution of the content was used to find the concentration that allowed a colony count within pre-established values, which were up to 250 colonies (Barbieri et al., 2015).

After dilution, $100 \mu \mathrm{l}$ of each concentration were pipetted in the petri dish with MacConkey media, Bile Esculin media and Brewer media to isolate enterobacteria, gram-positive cocci and total anaerobes, respectively. The contents were spread with a Drigalski handle in a circular motion until absorption of the liquid by culture media was complete. All media were incubated at $37^{\circ} \mathrm{C}$ for $48 \mathrm{~h}$. Anaerobic jars were used to incubated the Brewer media. After the incubation period, the total colony-forming units were evaluated (Vahjen et al., 1998).

\section{Experiment III - performance}

A total of 768 birds were housed in 64 floor pens, each with an area of $1.26 \mathrm{~m}^{2}(0.90 \mathrm{~m} \times 1.40 \mathrm{~m})$ and covered with recycled rice husk (second utilisation) as litter. The 8 experimental diets were randomly distributed into 8 replications with 12 birds each. Feeders and drinkers were the tubular and nipple type, respectively. A 24-h lighting programme was used in the first 2 weeks and then an 18-h programme was used subsequently. A data logger located at bird height recorded every $2 \mathrm{~h}$ the maximum, minimum and instantaneous average of environmental temperature, relative humidity and black globe temperature: $28.62 \pm 4.96^{\circ} \mathrm{C}$, $18.03 \pm 2.73^{\circ} \mathrm{C}, 22,43 \pm 4.27^{\circ} \mathrm{C}, 84.89 \pm 3.67 \%$, $51.56 \pm 10.38 \%, 71.86 \pm 12.69 \%, 28.12 \pm 1.86^{\circ} \mathrm{C}$, $18.27 \pm 3.72^{\circ} \mathrm{C}$ and $22.63 \pm 4.26^{\circ} \mathrm{C}$, respectively.

The performance was evaluated in accumulated periods 1-14, 1-21 and 1-42 d, considering the following variables: BW gain, feed intake and feed: gain ratio. Mortality was recorded daily to correct the feed intake and feed:gain ratio in each evaluation period by the average number of birds and by the weight of dead birds, respectively. Viability [100 -mortality (\%)] and production efficiency factor were calculated at the end of the experiment at $42 \mathrm{~d}$.

\section{Statistical analysis}

Results were analysed by Statistical Analysis System software (SAS Institute, 2012). Effects were considered significant at $P \leq 0.05$. All data were submitted to analysis of variance by the MIXED procedure. When necessary, differences between treatments were studied by comparing least squares means (LSMEANS) calculated by PDIFF (Compared Pairwise). The statistical model was:

$$
\begin{aligned}
y_{i j k l}= & \mu+a_{i}+b_{j}+c_{k}+(a \times b)_{i j}+(a \times c)_{i k} \\
& +(b \times c)_{j k}+(a \times b \times c)_{i j k}+e_{i j k l},
\end{aligned}
$$

where $y_{i j k l}=$ response variable of broilers fed on lipid sources $(i)$, lysophospholipids $(j)$ and organic acids $(k)$, in replication $l$. $\mu=$ overall mean value for y. $a_{i}=$ fixed effect of lipid sources. $b_{j}=$ fixed effect of lysophospholipids. $c_{k}=$ fixed effect of organic acids. $(a \times b)_{I J}=$ interaction of lipid sources with lysophospholipids. $(a \times c)_{i k}=$ interaction of lipid sources with organic acids. $(b \times c)_{j k}=$ interaction of lysophospholipids with organic acids. $(a \times b \times c)$ $i j k=$ triple interaction among lipid sources, lysophospholipids and organic acids. $e_{i j k l}=$ error term.

Data that did not show residual normality (verified by Shapiro-Wilk test by UNIVARIATE procedure) were submitted to logarithmic transformation. In the cases where data transformation was not enough to meet the statistical assumptions, the non-parametric Kruskal-Wallis test was applied through the NPAR1WAY procedure.

\section{RESULTS}

\section{Nutrient balance}

There was an interaction of lipid sources with lysophospholipids on ADL (Table 3), which improved with lysophospholipids addition in T-containing diets $(P<0.01)$ (Figure, a). Diets with $\mathrm{S}$ had greater ADL, regardless of lysophospholipids inclusion 
Table 3. Faecal apparent digestibility (\%) of dry matter $(A D D M)$, nitrogen $(A D N)$, lipid $(A D L)$ and gross energy corrected by nitrogen balance $\left(A D G E_{N}\right)$ of broilers fed maize-baseddiets $(10-14-d \text { period })^{1}$

\begin{tabular}{lccccc}
\hline & & \multicolumn{4}{c}{ Starter phase $^{3}$} \\
\cline { 3 - 6 } Effects $^{2}$ & & ADDM & ADN & ADL & ADGE $_{\mathrm{N}}$ \\
\hline \multirow{2}{*}{ Lipid } & $\mathrm{S}$ & 70.4 & 62.0 & 80.1 & 75.9 \\
& $\mathrm{~T}$ & 70.7 & 61.8 & 75.1 & 74.7 \\
LP & + & 70.6 & 62.1 & 77.9 & 75.5 \\
& - & 70.5 & 61.7 & 77.3 & 75.2 \\
OA & + & 70.5 & 62.2 & 77.9 & 75.1 \\
& - & 70.5 & 61.7 & 77.2 & 75.5 \\
SEM & & 0.17 & 0.31 & 0.39 & 0.20 \\
\hline
\end{tabular}

\begin{tabular}{lrrrr}
\hline Source of variation & \multicolumn{4}{c}{ Probability } \\
\hline Lipid & 0.376 & 0.755 & $<0.001$ & 0.002 \\
LP & 0.851 & 0.549 & 0.174 & 0.501 \\
OA & 0.935 & 0.380 & 0.106 & 0.236 \\
Lipid $\times$ LP & 0.128 & 0.337 & 0.016 & 0.093 \\
Lipid $\times$ OA & 0.139 & 0.336 & 0.465 & 0.051 \\
LP $\times$ OA & 0.830 & 0.226 & 0.145 & 0.715 \\
Lipid $\times$ LP $\times$ AO & 0.325 & 0.234 & 0.182 & 0.306 \\
\hline
\end{tabular}

${ }^{1}$ Data represent means of 8 replicates ( $n=7$ per replicate) in a treatment group.

${ }^{2} \mathrm{LP}$, lysophospholipids; OA, organic acids; S, soybean oil; T, beef tallow; +, presence of additive; -, absence of additive.

${ }^{3}$ Values expressed in natural matter.

$(P<0.001)$. Furthermore, lipid sources influenced $\mathrm{ADGE}_{\mathrm{N}}$, which was higher in $\mathrm{S}$ diets. The ADDM and ADN were not affected by the treatments.

\section{Fat-soluble vitamins}

Hepatic concentration of vitamins A and $\mathrm{E}$ were not affected by the treatments (Table 4). The contrast between the lipid profile of $\mathrm{S}$ and $\mathrm{T}$ was not enough
Table 4. Fat-soluble vitamins concentration in the liver of broilers fed on maize-based diets $(14-d \text { old })^{1}$

\begin{tabular}{|c|c|c|c|c|c|}
\hline \multirow[b]{3}{*}{ Effects $^{2}$} & & \multicolumn{4}{|c|}{ Vitamins } \\
\hline & & \multicolumn{2}{|c|}{ A } & \multicolumn{2}{|c|}{ E } \\
\hline & & $\mathrm{m} \mathrm{g} / \mathrm{kg}^{3}$ & $\mathrm{mg}^{4}$ & $\mathrm{~m} \mathrm{~g} / \mathrm{kg}^{3}$ & $\mathrm{mg}^{4}$ \\
\hline \multirow[t]{2}{*}{ Lipid } & $\mathrm{S}$ & 2.07 & 0.152 & 0.94 & 0.030 \\
\hline & $\mathrm{T}$ & 2.09 & 0.130 & 0.84 & 0.022 \\
\hline \multirow[t]{2}{*}{ LP } & + & 2.01 & 0.140 & 0.84 & 0.025 \\
\hline & - & 2.15 & 0.141 & 0.94 & 0.026 \\
\hline \multirow[t]{2}{*}{$\mathrm{OA}$} & + & 2.22 & 0.180 & 0.82 & 0.023 \\
\hline & - & 1.93 & 0.102 & 0.96 & 0.029 \\
\hline SEM & & 0.130 & 0.0219 & 0.064 & 0.0039 \\
\hline Source of variation & & \multicolumn{4}{|c|}{ Probability } \\
\hline Lipid & & 0.952 & 0.940 & 0.420 & 0.209 \\
\hline LP & & 0.616 & 0.450 & 0.422 & 0.564 \\
\hline $\mathrm{OA}$ & & 0.297 & 0.331 & 0.287 & 0.472 \\
\hline Lipid $\times$ LP & & 0.825 & 0.743 & 0.459 & 0.440 \\
\hline Lipid $\times$ OA & & 0.481 & 0.792 & 0.825 & 0.340 \\
\hline $\mathrm{LP} \times \mathrm{OA}$ & & 0.532 & 0.772 & 0.971 & 0.386 \\
\hline Lipid $\times \mathrm{LP} \times \mathrm{AO}$ & & 0.295 & 0.272 & 0.417 & 0.925 \\
\hline
\end{tabular}

${ }^{1}$ Data represent means of 8 replicates $(n=1$ per replicate) in a treatment group.

${ }^{2} \mathrm{LP}$, lysophospholipids; OA, organic acids; S, soybean oil; T, beef tallow; +, presence of additive; -, absence of additive.

${ }^{3}$ Data submitted to $\log$ transformation.

${ }^{4}$ Variables submitted to non-parametric test of Kruskal-Wallis.

to significantly alter the results, even with the additives addition.

\section{Jejunal microbiota}

In the experimental conditions of this study, there was no growth of total enterobacteria in jejunum samples, which were below the detection a.

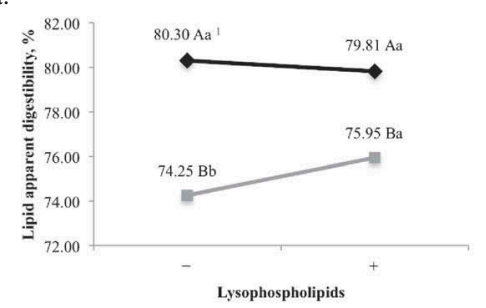

c.

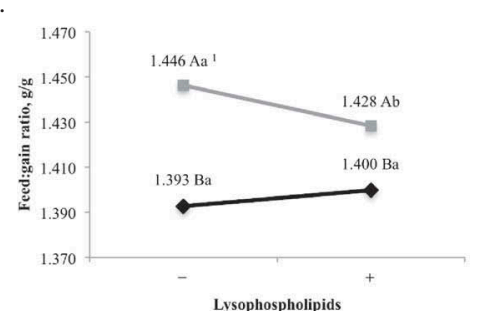

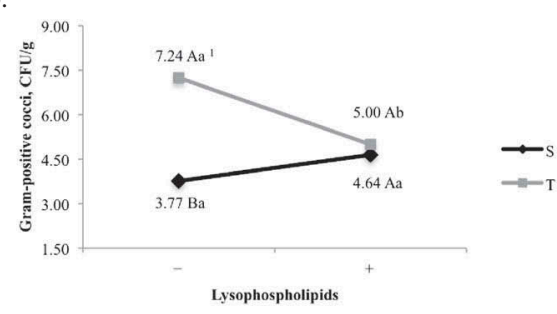

d.

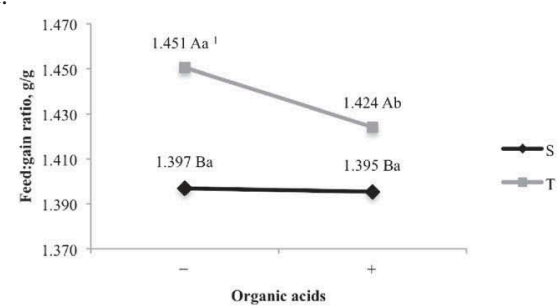

Figure. Interactions of lipid sources with the additives on faecal apparent digestibility of lipids at 10-14-d period (a), on gram-positive cocci count in the jejunum at $14 d(b)$ and on feed:gain ratio at $21 d$ of broilers ( $c$ and $d)$. ${ }^{1}$ Different letters, uppercase in the columns and lowercase in the rows, indicate significant difference at $5 \%$ probability. S, soybean oil; T, beef tallow. 
Table 5. Jejunal microbiology of broilers fed on maize-based diets $(14-d \text { old })^{1}$

\begin{tabular}{llll}
\hline & & \multicolumn{2}{c}{ Microbiology, CFU $/ \mathrm{g}^{3}$} \\
\cline { 3 - 4 } Effects $^{2}$ & & Gram-positive cocci & Total anaerobes \\
\hline Lipid & $\mathrm{S}$ & 4.20 & 7.21 \\
& $\mathrm{~T}$ & 6.12 & 8.48 \\
LP & + & 4.82 & 7.82 \\
& - & 5.50 & 7.88 \\
OA & + & 4.73 & 7.70 \\
& - & 5.59 & 8.00 \\
SEM & & 0.402 & 0.188 \\
\hline
\end{tabular}

\begin{tabular}{lcc}
\hline Source of variation & \multicolumn{2}{c}{ Probability } \\
\hline Lipid & 0.014 & $<0.001$ \\
LP & 0.372 & 0.863 \\
OA & 0.260 & 0.398 \\
Lipid $\times$ LP & 0.044 & 0.183 \\
Lipid $\times$ OA & 0.944 & 0.946 \\
LP $\times$ OA & 0.606 & 0.313 \\
Lipid $\times$ LP $\times$ AO & 0.185 & 0.139 \\
\hline
\end{tabular}

${ }^{1}$ Data represent means of 8 replicates $(n=1$ per replicate) in a treatment group.

${ }^{2} \mathrm{LP}$, lysophospholipids; OA, organic acids; S, soybean oil; T, beef tallow; +, presence of additive; -, absence of additive.

${ }^{3} \mathrm{UFC} / \mathrm{g}$, colony forming units per $\mathrm{g}$ of sample. Data submitted to log transformation.

threshold. There was interaction between lipid sources and lysophospholipids inclusion on grampositive cocci (Table 5). In diets without lysophospholipids, $\mathrm{S}$ provided lower amount of gram-positive cocci than $\mathrm{T}(P<0.01)$ (Figure, b); however, the presence of lysophospholipids decreased the number of gram-positive cocci in jejunum of T-fed broilers $(P<0.05)$, leading to similar results to those obtained with $\mathrm{S}$. Total anaerobic microorganisms were found in lower quantities in S-containing diets.

\section{Performance}

The results of broiler performance in the initial phase and the total period are presented in Table 6. At d 14, there was no interaction between the studied factors. A positive effect of $\mathrm{S}$ was observed on BW gain. Feed intake was not affected. S and organic acids inclusion improved feed:gain ratio. During this phase, no effect of lysophospholipids was found.

At $21 \mathrm{~d}$, broilers fed on $\mathrm{S}$ diets presented greater BW gain and feed intake. In this period, there was an interaction between lipid sources and lysophospholipids on feed:gain ratio (Figure, c). Lipid sources also interacted with organic acids on feed:gain ratio, as shown in the Figure (d). In both interactions, $\mathrm{S}$ promoted better feed:gain ratio than $\mathrm{T}(P<0.001)$; however, lysophospholipids $(P<0.05)$ and organic acids $(P<0.01)$ addition improved feed:gain ratio of $\mathrm{T}$ diets, showing that the additives are most effective in diets with saturated lipid sources.

Over the entire trial (1-42 d), broilers fed on S had the greatest BW gain and better feed:gain ratio compared with those fed on $\mathrm{T}$, being in accordance with results observed in the early stages. Lysophospholipid inclusion provided greater BW

Table 6. Performance of broilers fed on maize-based diets ${ }^{1}$

\begin{tabular}{|c|c|c|c|c|c|c|c|c|c|c|c|c|}
\hline \multirow[b]{3}{*}{ Effects $^{2}$} & & \multicolumn{11}{|c|}{ Performance ${ }^{3}$} \\
\hline & & \multicolumn{3}{|c|}{$1-14 d$} & \multicolumn{3}{|c|}{$1-21 \mathrm{~d}$} & \multicolumn{5}{|c|}{$1-42 \mathrm{~d}$} \\
\hline & & $\begin{array}{l}\text { BW } \\
\text { gain }\end{array}$ & $\begin{array}{l}\text { Feed } \\
\text { intake }\end{array}$ & $\begin{array}{l}\text { Feed: } \\
\text { gain } \\
\text { ratio }\end{array}$ & $\begin{array}{l}\text { BW } \\
\text { gain }\end{array}$ & $\begin{array}{c}\text { Feed } \\
\text { intake }\end{array}$ & $\begin{array}{l}\text { Feed: } \\
\text { gain } \\
\text { ratio }\end{array}$ & BW gain & $\begin{array}{c}\text { Feed } \\
\text { intake }\end{array}$ & $\begin{array}{l}\text { Feed: } \\
\text { gain } \\
\text { ratio }\end{array}$ & Viability $^{4}$ & $\mathrm{PEF}^{5}$ \\
\hline \multirow[t]{2}{*}{ Lipid } & $\mathrm{S}$ & 418 & 545 & 1.306 & 924 & 1288 & 1.396 & 2916 & 4789 & 1.656 & 96.1 & 401 \\
\hline & $\mathrm{T}$ & 404 & 541 & 1.341 & 885 & 1268 & 1.437 & 2867 & 4743 & 1.671 & 95.6 & 390 \\
\hline \multirow[t]{2}{*}{ LP } & + & 412 & 543 & 1.324 & 908 & 1279 & 1.414 & 2912 & 4771 & 1.660 & 94.5 & 394 \\
\hline & - & 410 & 543 & 1.324 & 902 & 1277 & 1.419 & 2871 & 4761 & 1.667 & 97.1 & 398 \\
\hline \multirow[t]{2}{*}{$\mathrm{OA}$} & + & 414 & 542 & 1.310 & 905 & 1272 & 1.410 & 2902 & 4764 & 1.657 & 95.1 & 395 \\
\hline & - & 408 & 544 & 1.337 & 905 & 1285 & 1.424 & 2881 & 4767 & 1.670 & 96.6 & 397 \\
\hline SEM & & 2.2 & 2.1 & 0.0052 & 4.1 & 4.3 & 0.0041 & 10.1 & 15.3 & 0.0027 & 0.72 & 3.1 \\
\hline Source of variation & & & & & & & Probabili & & & & & \\
\hline Lipid & & $<0.001$ & 0.457 & $<0.001$ & $<0.001$ & 0.022 & $<0.001$ & 0.013 & 0.151 & 0.003 & 0.751 & 0.090 \\
\hline LP & & 0.675 & 0.921 & 0.996 & 0.404 & 0.798 & 0.362 & 0.039 & 0.761 & 0.142 & 0.066 & 0.521 \\
\hline $\mathrm{OA}$ & & 0.165 & 0.686 & 0.005 & 0.981 & 0.124 & 0.023 & 0.284 & 0.917 & 0.016 & 0.230 & 0.711 \\
\hline Lipid $\times$ LP & & 0.295 & 0.857 & 0.700 & 0.311 & 0.669 & 0.042 & 0.467 & 0.739 & 0.845 & 0.100 & 0.387 \\
\hline Lipid $\times$ OA & & 0.674 & 0.804 & 0.657 & 0.554 & 0.591 & 0.043 & 0.401 & 0.893 & 0.789 & 0.163 & 0.493 \\
\hline $\mathrm{LP} \times \mathrm{OA}$ & & 0.317 & 0.226 & 0.994 & 0.729 & 0.557 & 0.380 & 0.816 & 0.764 & 0.716 & 0.314 & 0.700 \\
\hline Lipid $\times \mathrm{LP} \times \mathrm{OA}$ & & 0.989 & 0.274 & 0.067 & 0.730 & 0.392 & 0.345 & 0.629 & 0.971 & 0.436 & 0.571 & 0.546 \\
\hline
\end{tabular}

${ }^{1}$ Data represent means of 8 replicates $(n=12$ per replicate) in a treatment group.

${ }^{2} \mathrm{LP}$, lysophospholipids; OA, organic acids; S, soybean oil; T, beef tallow; +, presence of additive; -, absence of additive.

${ }^{3}$ Values expressed in g. Viability was expressed in \%.

${ }^{4}$ Variable submitted to non-parametric test of Kruskal-Wallis.

${ }^{5} \mathrm{PEF}$, production efficiency factor: [([VIAB $\left.\left.\left.\times \mathrm{ADG}\right] / \mathrm{F}: \mathrm{G}\right) / 10\right]$, where VIAB, ADG and F:G are viability, average daily gain and feed:gain ratio, respectively. 
gain, and the organic acids, on the other hand, improved the feed:gain ratio. However, it is noted at this period that the additives showed only main effects, with no interactions between factors. Feed intake, viability and productive efficiency index were not significantly altered by the diets.

\section{DISCUSSION}

The greatest ADL provided with S consequently improved the $\mathrm{ADGE}_{\mathrm{N}}$, demonstrating the clearly superiority of S. Higher digestibility of S compared with $\mathrm{T}$ was also observed by several authors (Dänicke et al., 2000; Preston et al., 2001; Ferreira et al., 2005; Fascina et al., 2009). There are many factors that influence the fat and oil digestibility. Among others, it has already been shown that the degree of saturation (Leeson and Summers, 1976), the amount of free fatty acids (Vila and Esteve-Garcia, 1996) and the position of the fatty acid in the triglyceride molecule (Renner and Hill, 1961) affect the utilisation of dietary lipids by birds.

Also, the physiological and metabolic factors may influence lipid digestion, which is dependent on the emulsification process by surfactant action of the bile salts. However, in the early stages of life, the birds have insufficient quantities of bile salts, which represent a critical point that can be optimised in the digestion of lipids. It is possible that the action of lysophospholipids on the ADL of $\mathrm{T}$ diets may have complemented the endogenous bile action, which appears to have low efficacy against the higher amounts of saturated fatty acids (Krogdahl, 1985). In this way, Alzawqari et al. $(2010,2011)$ reported an increase in saturated fat digestibility in diets supplemented with bile salts.

The conversion of phospholipids into lysophospholipids by enzymatic action is another fundamental stage in the lipid digestion process. The action of the phospholipase enzyme in fat absorption has been supported in studies with turkeys, having a marked action in the first weeks (Santos Jr et al., 2004). However, the use of phospholipase in the diet affects certain concerns regarding heat treatment in the extrusion and pelletisation process or in combination with other additives such as organic acids, which may change the optimal $\mathrm{pH}$ range of the enzyme. On the other hand, the lysophospholipids are fat molecules that have greater stability, admitting its use without major concerns related to temperature and $\mathrm{pH}$.

It is known that the lipids digestibility affects the absorption of fat-soluble dietary components, which are dependent on the emulsification process to be absorbed by a micellar complex. Nevertheless, in this experiment, it was not possible to observe treatment effect on liver concentration of vitamins A and E. Knarreborg et al. (2004) observed that the bioavailability of tocopherol molecules depends on the good conditions of emulsion and micelle formation, while favourable conditions for undesired bacterial growth cause negative effects. Dänicke et al. (1997) observed a higher concentration of vitamin $\mathrm{A}$ in the liver of birds fed with a higher content of polyunsaturated fatty acids derived from $\mathrm{S}$ compared with $\mathrm{T}$. However, these studies used diets with high concentrations of soluble pentosanes, which dramatically increase intestinal viscosity, adding contrast between the digestion of fats and oils.

The microbial count of jejunal samples indicates that lysophospholipids were effective in T-containing diets, minimising the negative impact of a higher quantity of saturated fatty acids from $\mathrm{T}$ on gram-positive cocci count. This decrease can be explained by the antimicrobial effect of lysophospholipids, which may have occurred in two ways. The lysophospholipids may have acted directly on the gram-positive microorganisms altering the cell membrane permeability, leading to damage in the bacteria integrity through ionic imbalance (Coonrod and Yoneda, 1983; Silva Jr, 2009; Arouri and Mouritsen, 2013). The second cause is related to the greater utilisation of $\mathrm{T}$ that resulted in lower amounts of substrate in the intestinal lumen. This finding suggested that the lysophospholipids could contribute to the reduction of the amount of growth-depressing metabolites produced by gram-positive bacteria, which is one of the beneficial factors attributed to the antibiotic utilisation (Huyghebaert et al., 2011).

The effect of lysophospholipids on the intestinal microbiota of broilers suggests further investigations, especially for microorganisms of particular interest in lipid digestion such as in the case of Enterococcus faecium and Clostridium perfringens (Knarreborg et al., 2002a). Organic acids did not changed jejunal microbiology probably due to the potential acidification that occurs in the proximal organs of the gastrointestinal tract, being removed from ingesta as a result of metabolism and absorption processes before reaching the Meckel's diverticulum (Bolton and Dewar, 1965). The most pronounced effect at the beginning of the digestive tract may be the $\mathrm{pH}$ decrease and bacterial control in subsequent segments of the intestine (Müjdat et al., 1999; Pirgozliev et al., 2008; Abbas et al., 2011); however, no significant results were found in the present study.

The diets with $\mathrm{S}$ provided lower amounts of total anaerobic microorganisms in the jejunum. The natural amount of bile salts and enzymes 
involved in bird lipid digestion may not be sufficient to efficiently emulsify the fatty acids of $\mathrm{T}$, which have large portions fully saturated. The relationship between the low digestibility of saturated fat with the intestinal microbiota was reported by Dänicke et al. (1999). Knarreborg et al. (2002b) confirmed the increase of undesirable bacterial growth due to higher amounts of saturated fatty acids in the diet. In turn, the increased amount of microorganisms affects the bile salt integrity by the bacterial cholyltaurine hydrolase activity (Knarreborg et al., 2002a), which affects the digestibility and performance of chickens (Feighner and Dashkevicz, 1987). Additionally, Maisonnier et al. (2003) showed loss of bile salts caused by the intestinal microbiota. Therefore, the improvement of ADL caused by lysophospholipids in $\mathrm{T}$ diets may also be associated to antimicrobial effect.

Results of $\mathrm{ADL}$ and $\mathrm{ADGE}_{\mathrm{N}}$ extended to broiler performance, confirming researches that observed better performance in consensus with higher digestibility coefficients due to lipid sources (Dänicke et al., 1997) and emulsifiers (Zhang et al., 2011). The interaction between the lipid sources and lysophospholipids on digestibility was also observed on feed:gain ratio in the starter phase, where lysophospholipids increased feed:gain ratio only in diets with $\mathrm{T}$. For the total period (1-42 d), the lipid sources and lysophospholipids affected performance without interactions. Due to a higher demand for energy in the final stages, the lysophospholipids presence was effective in increasing broiler BW gain independent of the inclusion of $\mathrm{S}$ or $\mathrm{T}$. Zhang et al. (2011) found higher values of apparent metabolisable energy (AME) in diets with lysophospholipids only after $35 \mathrm{~d}$, confirming the greatest pronouncement of lysophospholipids on energy demand in the final phase. Furthermore, the lysophospholipids derived from rice bran was recommended as a source of energy for broilers with beneficial effects on performance and fat digestibility (Raju et al., 2011).

Organic acids improved feed:gain ratio in all periods, and presented positive effect in $\mathrm{T}$ diets within interaction with lipid sources at $\mathrm{d} 21$. Although no organic acid effect was observed on jejunal microbiological count, the positive effect of the organic acids primarily on diets with $\mathrm{T}$ is justified by the antimicrobial effect, probably occurring in the proximal portions of the gastrointestinal tract. Several studies show the benefits of organic acids in diets for broilers (Abdel-Fattah et al., 2008; Adil et al., 2010), with accentuated effects in the presence of microbial challenge (Abbas et al., 2011).

In conclusion, the property of lipid sources is a decisive factor that strongly affects digestibility, microbiota and performance of broilers.
The additives interacted with saturation degree of lipid sources up to $21 \mathrm{~d}$, improving diets with $\mathrm{T}$. There were no positive interaction effects (synergy) between the additives on the variables studied. However, the findings suggest that lysophospholipids increase $\mathrm{BW}$ gain and organic acids improve feed:gain ratio from 1 to $42 \mathrm{~d}$, regardless of lipid source.

\section{ACKNOWLEDGEMENTS}

The authors thank the São Paulo Research Foundation (FAPESP, Brazil) for their financial support (Proc 2012/08536-4) and scholarship (Proc 2012/11370-0). We also thank the Kemin, Nutriacid/Btech and SBS minérios for donating the lysophospholipids, organic acids and kaolin, respectively.

\section{DISCLOSURE STATEMENT}

No potential conflict of interest was reported by the authors.

\section{FUNDING}

This work was supported by the São Paulo Research Foundation (FAPESP, Brazil); [Proc 2012/08536-4]; [Proc 2012/11370-0].

\section{ORCID}

G. V. Polycarpo 구 http://orcid.org/0000-00016282-3297

\section{REFERENCES}

Abbas, R.Z., Munawar, S.H., Manzoor, Z., Iobal, Z., Khan, M. N., Saleemi, M.K., Zia, M.A. \& Yousaf, A. (2011) Anticoccidial effects of acetic acid on performance and pathogenic parameters in broiler chickens challenged with Eimeria tenella. Pesquisa Veterinária Brasileira, 31: 99103. doi:10.1590/S0100-736X2011000200001

Abdel-Fattah, S.A., El-Sanhoury, M.H., Mednay, N.M. \& Abdelazeem, F. (2008) Thyroid activity, some blood constituents, organs morphology and performance of broiler chicks fed supplemental organic acids. International Journal of Poultry Science, 7: 215-222. doi:10.3923/ ijps.2008.215.222

Adil, S., Banday, T., Bhat, G.A., Mir, M.S. \& Rehman, M. (2010) Effect of dietary supplementation of organic acids on performance, intestinal histomorphology, and serum biochemistry of broiler chicken. Veterinary Medicine International, 2010: 479-485. doi:10.4061/2010/479485

Alakomi, H.-L., Skyttä, E., Saarela, M., Mattila-Sandholm, T., Latva-Kala, K. \& Helander, I.M. (2000) Lactic acid permeabilizes gram-negative bacteria by disrupting the outer membrane. Applied and Environmental Microbiology, 66: 2001-2005. doi:10.1128/AEM.66.5.2001-2005.2000

AlzawQari, M., Kermanshahi, H. \& Moghaddam, H.N. (2010) The effect of glycine and desiccated ox bile 
supplementation on performance, fat digestibility, blood chemistry and ileal digesta viscosity of broiler chickens. Global Veterinaria, 5: 187-194.

Alzawoari, M., Moghaddam, H.N., Kermanshahi, H. \& RajI, A. R. (2011) The effect of desiccated ox bile supplementation on performance, fat digestibility, gut morphology and blood chemistry of broiler chickens fed tallow diets. Journal of Applied Animal Research, 39: 169-174. doi:10.1080/09712119.2011.580999.

AOAC (1990) Official Methods of Analysis, 15th edn. (Washington, DC, Association of Official Analytical Chemists).

Arouri, A. \& Mouritsen, O.G. (2013) Membrane-perturbing effect of fatty acids and lysolipids. Progress in Lipid Research, 52: 130-140. doi:10.1016/j.plipres.2012.09.002

Azman, M.A. \& CifTCI, M. (2004) Effects of replacing dietary fat with lecithin on broiler chicken zootechnical performance. Revue de Médecine Vétérinaire, 155: 445-448.

Barbieri, A., Polycarpo, G.V., Cardoso, R.G.A., Silva, K.M., Dadalt, J.C., Madeira, A.M.B.N., Sousa, R.L.M. Albuquerque, A. \& Cruz-Polycarpo, V.C. (2015) Effect of probiotic and organic acids in an attempt to replace the antibiotics in diets of broiler chickens challenged with Eimeria spp. International Journal of Poultry Science, 14: 606614. doi:10.3923/ijps.2015.606.614

Bligh, E.G. \& Dyer, W.J. (1959) A rapid method for total lipid extraction and purification. Canadian Journal of Biochemistry and Physiology, 37: 911-917. doi:10.1139/o59-099

Bolton, W. \& Dewar, W.A. (1965) The digestibility of acetic, propionic and butyric acids by the fowl. British Poultry Science, 6: 103-105. doi:10.1080/00071666508415562

Christie, W.W. (1982) A simple procedure for rapid transmethylation of glycerolipids and cholesterol esters. Journal of Lipid Research, 23: 1072-1075.

CoOnRoD, J.D. \& YonedA, K. (1983) Detection and partial characterization of antibacterial factor(s) in alveolar lining material of rats. Journal of Clinical Investigation, 71: 129-141. doi:10.1172/JCI110741

Dänicke, S., Jeroch, H., Böttcher, W. \& Simon, O. (2000) Interactions between dietary fat type and enzyme supplementation in broiler diets with high pentosan contents: effects on precaecal and total tract digestibility of fatty acids, metabolizability of gross energy, digesta viscosity and weights of small intestine. Animal Feed Science and Technology, 84: 279-294.

DÄnicke, S., Simon, O., Jeroch, H. \& Bedford, M. (1997) Interactions between dietary fat type and xylanase supplementation when rye-based diets are fed to broiler chickens 2. Performance, nutrient digestibility and the fat-soluble vitamin status of livers. British Poultry Science, 38: 546-556. doi:10.1080/00071669708418035

Dänicke, S., Vahjen, W., Simon, O. \& Jeroch, H. (1999) Effects of dietary fat type and xylanase supplementation to ryebased broiler diets on selected bacterial groups adhering to the intestinal epithelium, on transit time of feed, and on nutrient digestibility. Poultry Science, 78: 1292-1299. doi:10.1093/ps/78.9.1292

Fascina, V.B., Carrijo, A.S., Souza, K.M.R., Garcia, A.M.L., Kiefer, C. \& SARTori, J.R. (2009) Soybean oil and beef tallow in starter broiler diets. Brazilian Journal of Poultry Science, 11 249-256.

FeighneR, S.D. \& Dashkevicz, M.P. (1987) Subtherapeutic levels of antibiotics in poultry feeds and their effects on weight gain, feed efficiency, and bacterial cholyltaurine hydrolase activity. Applied and Environmental Microbiology, 53: 331-336.

Ferreira, A.F., Andreotti, M.O., Carrijo, A.S., Souza, K.M.R., FAscina, V.B. \& Rodrigues, E.A. (2005) Nutritional value of soybean oil, beef tallow and their blends of diets for broilers. Acta Scientiarum. Animal Sciences, 27: 213-219.
Huang, J., Yang, D., GaO, S. \& Wang, T. (2008) Effects of soylecithin on lipid metabolism and hepatic expression of lipogenic genes in broiler chickens. Livestock Science, 118: 53-60. doi:10.1016/j.livsci.2008.01.014

Huang, J., YANG, D. \& WANG, T. (2007) Effects of replacing soy-oil with soy-lecithin on growth performance, nutrient utilization and serum parameters of broilers fed cornbased diets. Asian-Australasian Journal of Animal Sciences, 20: 1880-1886. doi:10.5713/ajas.2007.1880

Huyghebaert, G., Ducatelle, R. \& Van Immerseel, F. (2011) An update on alternatives to antimicrobial growth promoters for broilers. The Veterinary Journal, 187: 182-188. doi:10.1016/j.tvjl.2010.03.003

Jansen, M., Nuyens, F., Buyse, J., Leleu, S. \& Van Campenhout, L. (2015) Interaction between fat type and lysolecithin supplementation in broiler feeds. Poultry Science, 94: 2506-2515. doi:10.3382/ps/pev181

Knarreborg, A., Engberg, R.M., Jensen, S.K. \& Jensen, B.B. (2002a) Quantitative determination of bile salt hydrolase activity in bacteria isolated from the small intestine of chickens. Applied and Environmental Microbiology, 68: 64256428. doi:10.1128/AEM.68.12.6425-6428.2002

Knarreborg, A., Lauridsen, A., Engberg, R.M. \& Jensen, A.K. (2004) Dietary antibiotic growth promoters enhance the bioavailability of $\alpha$-tocopheryl acetate in broilers by altering lipid absorption. Journal of Nutrition, 134: 1487-1492.

Knarreborg, A., Simon, M.A., Engberg, R.M., Jensen, B.B. \& Tannock, G.W. (2002b) Effects of dietary fat source and subtherapeutic levels of antibiotic on the bacterial community in the ileum of broiler chickens at various ages. Applied and Environmental Microbiology, 68: 5918-5924. doi:10.1128/AEM.68.12.5918-5924.2002

Kramer, J.K.G., Fellner, V. \& Dugan, M.E.R. (1997) Evaluating acid and base catalysts in the methylation of milk and rumen fatty acids with special emphasis on conjugated dienes and total trans fatty acids. Lipids, 32: 12191228. doi:10.1007/s11745-997-0156-3

KROGDAHL, A. (1985) Digestion and absorption of lipids in poultry. Journal of Nutrition, 115: 675-685.

Kussaibati, R., Guillaume, J. \& Leclerce, B. (1982) The effects of age, dietary fat and bile salts, and feeding rate on apparent and true metabolisable energy values in chickens. British Poultry Science, 23: 383-403. doi:10.1080/ 00071688208447973

LeEson, S. \& Summers, J.D. (1976) Fat ME values: the effect of fatty acid saturation. Feedstuffs, 48: 26-28.

Maisonnier, S., Gomez, J., Brée, A., Berri, C., BaÉza, E. \& CARRÉ, B. (2003) Effects of microflora status, dietary bile salts and guar gum on lipid digestibility, intestinal bile salts, and histomorphology in broiler chickens. Poultry Science, 82: 805-814. doi:10.1093/ps/82.5.805

Matterson, L.D., Potter, L.M., Stutz, M.W. \& Singsen, E.P. (1965) The Metabolizable Energy of Feed Ingredients for Chicks. Research Report 7. (Connecticut Storrs Agric. Exp. Sta., Storrs, CT)

Müjdat, A.L.P., KocabaĞLi, N. \& Kahraman, R. (1999) Effects of dietary supplementation with organic acids and zinc bacitracin on ileal microflora, $\mathrm{pH}$ and performance in broilers. Turkish Journal of Veterinary and Animal Sciences, 23: 451-455.

Pirgozliev, V., Murphy, T.C., Owens, B., George, J. \& McCann, M.E.E. (2008) Fumaric and sorbic acid as additives in broiler feed. Research in Veterinary Science, 84: 387-394. doi:10.1016/j.rvsc.2007.06.010

Polin, D., Wing, T.L., KI, P. \& Pell, K.E. (1980) The effect of bile acids and lipase on absorption of tallow in young chicks. Poultry Science, 59: 2738-2743. doi:10.3382/ ps.0592738

Preston, C.M., McCracken, K.J. \& Bedford, M.R. (2001) Effect of wheat content, fat source and enzyme 
supplementation on diet metabolisability and broiler performance. British Poultry Science, 42: 625-632. doi:10.1080/ 00071660120088443

Raju, M.V.L.N., Rama Rao, S.V., Chakrabarti, P.P., Rao, B.V.S. K., Panda, A.K., Prabhavathi Devi, B.L.A., Sujatha, V., Reddy, J.R.C., Shyam Sunder, G. \& Prasad, R.B.N. (2011) Rice bran lysolecithin as a source of energy in broiler chicken diet. British Poultry Science, 52: 769-774. doi:10.1080/00071668.2011.640929

Renner, R. \& Hill, F.W. (1961) Factors affecting the absorbability of saturated fatty acids in the chick. Journal of Nutrition, 74: 254-258.

Ricke, S.C. (2003) Perspectives on the use of organic acids and short chain fatty acids as antimicrobials. Poultry Science, 82: 632-639. doi:10.1093/ps/82.4.632

Rostagno, H.S., Albino, L.F.T., Donzele, J.L., Gomes, P.C., Oliveira, R.F., Lopes, D.C., Ferreira, A.S., Barreto, S.L.T. \& EUCLIDES, R.F. (2011) Tabelas brasileiras para aves e suinos: composição de alimentos e exigências nutricionais, 3rd edn, 252p. (Viçosa, MG, UFV, DZO).

Santos Jnr, A.A., Ferket, P.R., Grimes, J.L. \& Edens, F.W. (2004) Dietary supplementation of endoxylanases and fosfolipase for turkeys fed wheat-based rations. International Journal of Poultry Science, 3: 20-32. doi:10.3923/ ijps.2004.20.32

SAS Institute (2012) SAS/STAT ${ }^{\circledR}$ User's Guide. Version 9.3. (Cary, NC, SAS Institute Inc.).

SILVA JNR, A. (2009) Chemical and physiological interactions of acidifiers, probiotics, enzymes and lysophospholipids in the piglest digestion. Brazilian Journal of Animal Science, 38: 238245

Smedes, F. \& Thomasen, T.K. (1996) Evaluation of the Bligh \& Dyer lipid determination method. Marine Pollution Bulletin, 32: 681-688. doi:10.1016/0025-326X (96) 00079-3
StafFord, R.E. \& Dennis, E.A. (1988) Lysophospholipids as biosurfactants. Colloids and Surfaces, 30: 47-64. doi:10.1016/0166-6622(87)80203-2

TAMBlyn, K.C. \& ConNER, D.E. (1997) Bactericidal activity of organic acids in combination with transdermal compounds against Salmonella typhimurium attached to broiler skin. Food Microbiology, 14: 477-484. doi:10.1006/ fmic.1997.0112

Vahjen, W., Gläser, K., Schäfer, K. \& Simon, O. (1998) Influence of xylanase supplemented feed on the development of selected bacterial groups in the intestinal tract of broiler chicks. The Journal of Agricultural Science, 130: 489500. doi:10.1017/S0021859698005498

Van Immerseel, F., Russell, J.B., Flythe, M.D., Gantois, I., Timbermont, L., Pasmans, F., Haesebrouck, F. \& Ducatelle, R. (2006) The use of organic acids to combat Salmonella in poultry: a mechanistic explanation of the efficacy. Avian Pathology, 35: 182-188. doi:10.1080/ 03079450600711045

Vila, B. \& Esteve-Garcia, E. (1996) Studies on acid oils and fatty acids for chickens. II. Effect of free fatty acid content and degree of saturation of free fatty acids and neutral fat on fatty acid digestibility. British Poultry Science, 37: 119-130. doi:10.1080/00071669608417842

Zhang, B., Haitao, L., Zhao, D., Guo, Y. \& Barri, A. (2011) Effect of fat type and lysophosphatidylcholine addition to broiler diets on performance, apparent digestibility of fatty acids, and apparent metabolisable energy content. Animal Feed Science and Technology, 163: 177-184. doi:10.1016/j. anifeedsci.2010.10.004

Zhao, O., Zhao, P. \& Doyle, M.P. (2009) Inactivation of Salmonella and Escherichia coli O157: h7on lettuce and poultry skin by combinations of levulinic acid and sodium odecyl sulfate. Journal of Food Protection, 72: 928-936. 